\title{
Social Pressure and the Making of Wartime Civilian Protection Rules
}

\author{
Giovanni Mantilla \\ Department of Politics and International Studies (POLIS) \\ Christ's College \\ University of Cambridge \\ gm633@cam.ac.uk
}

\begin{abstract}
The protection of civilians from the dangers of warfare constitutes an imperative in contemporary global politics. Drawing on original multiarchival research, this article explains the codification of the core civilian protection rules within international humanitarian law in the 1970s. It argues that these crucial international rules resulted from the operation of two central mechanisms: Third-world and Socialist-led social pressure and a strategic, facesaving reaction to it, leadership capture, in the politicized context of Cold War and decolonization-era international social competition. I demonstrate the conditional effect of social pressure by a coalition of materially weaker Third World and Socialist states upon powerful reluctant states: the United States, the United Kingdom, and more surprisingly, the Soviet Union. Third World and Socialist social pressure fostered a curious US-USSR backstage collaboration I label leadership capture, decisively shaping the legal compromise embodied in the civilian protection rules of Additional Protocol I to the Geneva Conventions. Theoretically, this article furthers burgeoning IR work on the connection between social pressure, status competition, and international rule-making. Empirically it presents a new archives-based history of an intrinsically-important case in international law.
\end{abstract}

Forthcoming in the European Journal of International Relations 
Protecting civilians from warfare has seemingly become a normative imperative in contemporary global politics. It permeates key international organizations and practices, including the United Nations (UN) Security Council, peace-keeping (Dayal and Morjé Howard, 2017), and non-governmental organizations. It underpins established and nascent international legal frameworks, including international criminal law and the "Responsibility to Protect" doctrine (Bellamy, 2015). Overall, civilian protection increasingly appears central to current global governance.

Despite this centrality, the codification of the core civilian protection principles (distinction, proportionality, and precaution) in international humanitarian law (IHL) is recent and controversial. Only in 1977 did states enshrine concrete wartime civilian protection rules, and the result, important though it is, emerged in the form of partially flexible or indeterminate language (Dill, 2014; Kinsella, 2011). This legal design has arguably as much helped to protect civilians as it has licensed "systemic collateral damage" against them (Crawford, 2013). Why were binding civilian protection rules codified in the 1970s? Why were they designed so?

This article explains the 1970s codification of civilian protection largely as the outcome of Third World and Socialist states' social pressure leading to and during diplomatic negotiations, and a collaborative reaction to it by the United States (US) and the Soviet Union (USSR), which I label leadership capture. ${ }^{1}$ In the mid-1960s humanitarian outcry rose sharply after a major wave of wartime atrocity against civilians occurring amid the Cold War and decolonization. In this context, a majority coalition formed primarily by Third World and Socialist states demanded revisions to existing IHL, utilizing newfound advantages within key international forums to compel longstanding Western gatekeepers, the US and the United Kingdom (UK), to negotiate

\footnotetext{
${ }^{1}$ Leadership capture is a stronger version of what I elsewhere call covert pushback (Mantilla, 2018: 331-332).
} 
rules they had theretofore staunchly opposed. Concomitantly, growing American concern over atrocity in Vietnam helped to draw the US into legal revisions.

Social pressure then carried over to the processes of treaty drafting and negotiation. Initially, leading Western powers opposed firm or detailed legal restrictions on their combat practices. The majority of states, however, pushed for strict rules and prohibitions to protect civilians from the dangers of warfare. This divide mattered decisively, for in post-colonial international organization Western powers were a minority facing the prospect of certain losses via public votes in universal-membership forums, pitted against resolute majorities often uninterested in reaching consensus or compromise. Daunted by the prospect of prohibitionist wartime rules yet hampered by their minority position, the US-led Western group received a lifeline when the Soviet Union -- initially toeing the "extremist" line - switched gears and proposed backstage collaboration to jointly manage the pressures of multilateral negotiation and shepherd palatable compromises.

This explanation advances our understanding of social pressure in international politics by formulating a historically-grounded model connecting the macro politics of international social competition with process-level contentious dynamics and practices of multilateral codification. Despite its sensitivity to context and practice, this model can be fruitfully transposed to explain multilateral outcomes occurring under similar conditions. Empirically, I develop a new primarysource based history of the making of wartime civilian protection rules within treaty IHL, complicating claims about the persistently-colonial origins and development of this body of international law (Anghie, 2007: 316) as well as recent research positing civilian protection as the logical legal development of pre-existing normative change (Alexander, 2016: 48). 
The article is organized as follows. The first two sections discuss the puzzles and the limits of existing explanations. Next, I present my argument regarding the operation of social pressure on the postwar reconstruction of international law, hinging on the politics of social competition over status in the global normative hierarchy between West, East, and the decolonized world, and the complex functioning of the discourse and value of "humanity" amid such competitive politics. The detailed archives-based historical study follows. Finally, a concluding section discusses key theoretical implications and possible extensions.

\section{The Puzzles}

Three wartime civilian protection rules feature centrally in contemporary global governance:

- Combatants should target only combatants and military objects, distinguishing them from civilians and civilian objects, which should not be deliberately attacked (distinction);

- Attacks should be proportional to the military advantage being sought (proportionality);

- Combatants should take measures of precaution to avoid civilian casualties (precaution).

Although legal histories routinely affirm these rules as the longstanding core of IHL, their codification dates back only to the adoption in 1977 of two Additional Protocols (APs) to the Geneva Conventions. ${ }^{2}$ Puzzlingly, as late as 1965 leading Western powers, especially the US and the UK, considered enshrining such limits into treaty IHL to be militarily unrealistic and politically inconvenient. A US State Department cable to the American delegation participating at an International Conference of the Red Cross in 1965 bluntly stated: "Dept. considers [civilian protection rules] to deal with matters outside [the] normal scope of Red Cross activities and may

\footnotetext{
${ }^{2}$ The Hague Conventions of 1899 and 1907 contain language prohibiting personal and property damage to civilians under occupation, and to undefended towns. The Fourth Geneva Convention of 1949 more fully regulates the treatment of civilians living under occupation or in enemy territory. However, neither treaty delineates detailed restrictions on combat practices.
} 
have potential propaganda value for unfriendly governments in any area where civilians may be killed or injured... US will oppose any resolution directed against the US or Vietnam and which inhibits their freedom of action" (USNACP-1). With such opposition from powerful gatekeepers, how was civilian protection codified in the 1970s?

The rules adopted in 1977 combine general language prohibiting the deliberate targeting of civilian persons and objects with detailed rules fleshing out that general language. Those rules, however, introduce various subjective "judgment calls". In order to retain civilian immunity, for instance, civilians are enjoined to refrain from directly participating in hostilities, albeit without clearly defining what "direct participation" means. For their part, combatants are exhorted to take all "feasible" precautions and do "everything feasible" to prevent civilian harm, and called to weigh potential damage to civilians against their expectations of "concrete and direct military advantage". Scholars argue that these are overtly-subjective tests which, taken together, riddle Additional Protocol I (API) civilian protection rules with indeterminacy (Dill, 2014; Kinsella, 2011). For some, these features have made civilian protection via IHL at best partially ineffectual both in its wartime practice and post-facto legal adjudication, and at worst counterproductive to civilians, insofar as they can legitimate damage done to them with credible legal justification (Crawford, 2013). What explains this legal design?

\section{Existing Explanations}

The codification of civilian protection in the 1970 is commonly explained as a response to growing concern by the international community, especially the UN, over proliferating atrocity against civilians in the era of national liberation (Crawford, 2015: 38-39), with the Algerian conflict looming especially large (Kinsella, 2011: 127-136). The design of the civilian protection 
rules, in turn, is usually presented as a compromise between humanitarianism and military necessity, sometimes referencing the specific positions of Western states, or the Third and Socialist worlds (Aldrich, 1981: 777-782, 1986: 719-720; Best, 1994: 407-418; Partsch et al., 1982: 299318).

Recent work has moved from general contours to the more precise origins of the adopted language. Dill's analysis of the 1974-1977 negotiation proceedings, for instance, finds that the codified rules aligned with the American view in key places (2014: 96-105). Alexander argues that the acceptance of the APs, including the civilian protection articles in API "was achieved well before the [1970s] Conference", insofar as the key revisions to IHL were enabled by "prior battles and victories over the discursive possibilities" available to negotiating governments (2016: 17). These prior "battles won" were anti-colonialism, anti-imperialism, and opposition to Vietnam war atrocity, which jointly gave rise to a new "unarguable" value system that finally became enshrined into API.

Although this work highlights elements that should form part of any explanation, it misses the broader politics that underpinned the codification of civilian protection and undertheorizes the processes and practices that shaped its conclusion. On the one hand, while anti-colonialism, antiimperialism, and anti-atrocity sentiment (including due to Algeria and Vietnam) mattered tremendously as contextual factors behind IHL revisions, in the absence of focused Third World and Socialist pressure, deployed under particular institutional conditions and set against the broader context of social competition during the Cold War and decolonization, the US and UK would have hardly moved beyond their initial no-codification or "general principles only" stance regarding civilian protection. As late as 1967 they had long and quite deliberately ignored calls from the International Committee of the Red Cross (ICRC) to pursue revisions to the law (ICRC, 
1969: 16-21; Mantilla, n.d.: 4). Hence, Third World and Socialist entrepreneurship exerted through diplomatic practice leveraging a politicized context proved essential for disturbing the legal status-quo. And although Alexander (2015: 118-121, 124-125) traces the actions and positions of Third and Socialist world before and during the making of the APs, she does not theorize the precise institutional conditions and mechanisms enabling these actors to exert their influence nor analyzes the reactions they provoked.

Further, despite widespread agreement that the design of civilian protection rules represented a compromise, why and how the resulting compromises were struck remains unclear. Here, I show that the final language was strongly facilitated by face-saving backstage collaboration between the US and the USSR. This is not only a heretofore underappreciated instance of superpower collaboration amid the Cold War and decolonization but also, more broadly, a demonstration that civilian protection owes its codification to a complex configuration of: a politicized context, collective agency, institutionalized diplomatic contestation, and contingencies occurring in both the front and "backstage" of postwar multilateralism.

\section{The Argument}

Social Pressure and Status Politics

Social pressure can be defined as attempted non-material and non-coercive influence by some actors upon others, compelling target actors to meet an expectation under a threat of opprobrium. Social pressure mechanisms proliferate in an established IR literature highlighting states' need to foster or maintain their social reputation or standing in international society (Erickson, 2015: 24; Finnemore and Sikkink, 1998). Existing work generally focuses on explaining actor compliance with existing treaty (Risse et al., 1999) or public commitments (Schimmelfennig, 
2001), state socialization within international institutions (Johnston, 2008) or via rankings (Kelley, 2017), and broader dynamics of world-ordering through stigmatization (Adler-Nissen, 2014; Zarakol, 2011), or stratification through domestic policy change and diffusion (Towns, 2012).

My argument contributes to this literature by linking social pressure to international status competition (Towns and Rumelili, 2017) and then by applying these combined insights to understand processes and outcomes of international law-making. I build on Towns and Rumelili's claim that "it is through international hierarchy - the ordering of states as superior or inferior -that social pressure is exerted and states are prodded into action" (Towns and Rumelili, 2017: 758). Specifically, Towns and Rumelili theorize the competitive status dynamics generated by "relative" and "heterogenizing" standards. Relative standards are those according to which one actor's improvement is "directly and sometimes even causally related to the deterioration of another" (2017: 765). Heterogenizing standards are those that articulate dynamics of inclusion and exclusion, differentiating between types of actors, e.g. "good" or "bad" states. Together, relative and heterogenizing standards foster international social comparison and competition, "with each actor carefully instructed to watch the position and behavior of others" (Towns and Rumelili, 2017: 766). ${ }^{3}$ This theorization gives social pressure a more precise, confrontational, and competitive character than do mechanisms that hinge generally on states' general needs for self-esteem, good standing, peer recognition (Erickson, 2015: 24-28) or in-group conformity (Johnston, 2008: 86), and is distinct from arguments emphasizing norm emergence through persuasion (Finnemore and Sikkink, 1998: 898; Risse, 2000).

Empirically, much IR work highlights social pressure in multilateralism after the Cold War (Petrova, 2016; Price, 1998; Schimmelfennig, 2001), overlooking the pervasive and productive

\footnotetext{
${ }^{3}$ This contrasts with "absolute" and "homogenizing" hierarchies (Towns and Rumelili, 2017: 766-7).
} 
dynamics of state inter-group social competition during the making of postwar international order, especially during between the 1950s and 1970s. Limited research on this historical period so far emphasizes these dynamics (Acharya, 2018; Burke, 2010; Colgan and Miller, 2019; Jensen, 2016; Waltz, 2001). Overall, the extent to which different state groupings after World War II pursued status-seeking social competition through international institutions and processes remains vastly unexplored.

I begin to address this empirical gap here. I focus on multilateral diplomacy a key site of impression-management in international relations (Adler-Nissen, 2012) with face-saving and embarrassment-avoidance at its core (Nair, 2019). Domestic pressures can of course prove relevant, yet here they receive limited attention due to the overwhelmingly diplomatic origins and nature of the civilian protection codification process.

\section{"Humanity" and Social Competition in the Postwar Normative Hierarchy}

Global governance is as much a struggle over polysemic "universal values" (Pouliot and Thérien, 2018) as it is about public-goods provision. Pouliot and Thérien note that "in global governance legitimacy is generally sought after through a rhetoric of universal aspirations... the language of universal values, which intends to be all-inclusive and stand above politics, actually comes with a diversity of political priorities that often clash with one another" (2018: 59).

I argue that after World War II, the polysemic universal value of "humanity" became a relative and heterogenizing hierarchical fulcrum of contention among the major state groupings of the era (East, West, and the decolonized world) as they struggled for higher normative ground in international society. Crucially, "humanity" was a value and cause simultaneously exploitable for political gain and commanding of public adherence, even if only rhetorically. Given its polysemy 
and ambiguity, the international promotion of "humanity" could accommodate very diverse political orientations and policy agendas. Given its generalized normative centrality, "humanity" could function as an effective rhetorical weapon instrumental both for status-enhancement and for status-debasing amid social competition. And given its universality, the promotion of "humanity" also had a "disciplining" side, exerting a political pull that compelled public adherence (or at least lip-service) by most states.

It may seem a stretch to claim that after World War II most states subscribed to "humanity" as a shared value, or that the two most powerful states in the system, the US and USSR, competed over status in the same international normative hierarchy. Indeed, the Cold War and decolonization were intense social contests involving starkly divergent (even irreconcilable) ideologies and related normative packages: communism, socialism, liberalism, self-determination, trusteeship, etc. And yet, despite such social conflict, "humanity" (and its cognates, including "peacelovingness" and non-aggression) seemed at the time broad enough idioms that most state ideologies could construe and claim as their own (Betts, 2016; Hoffman, 2010; Özsu, 2016). Betts notes that after the war, "humanity remained a slippery term, and could be aligned to various causes, be they liberal or Christian, fascist, communist or racist" (2016: 62) Scholars of humanitarianism argue that, despite postwar political fractures, in the twentieth century "a secularized humanity became more fashionable and more widely regarded as providing the transcendent foundations for an international community defined by considerable diversity" (Barnett, 2011: 101-102).

This is perhaps easier to understand vis-à-vis the liberal West and leading powers, the US, the UK, and France, which despite the wartime atrocity they committed in places like Korea, Vietnam, Kenya, Aden, and Algeria, continued to present themselves as beacons of liberty and 
democracy. More interestingly, it also seemed true of a Soviet Union bent on promoting revolution and national liberation, presenting itself as an "Empire of Justice" despite its own penchant for atrocity. As Westad asserts, "like the United States, the Soviet state was founded on ideas and plans for the betterment of humanity" (2005: 39) whose "role was to help make the world safe for revolution and thereby assist in the progress of humankind" (2005: 72). Further, as Betts notes, “the Soviet Union's growing interest in humanity was also forged as a Cold War weapon to attack the West. This was evident in the USSR's involvement with the [1949] Geneva Conventions... it positioned itself as the Guardian of the Convention's spirit of universalism" (2016: 65; Mantilla, 2018). For its part, the Third World ferociously and successfully legitimated anti-colonialism and self-determination in the 1950s and 1960s (Crawford, 2002; Jacobson, 1962). And since the postwar promotion of "humanity" to a large extent merged with anti-colonialism and antiimperialism (Eckel, 2010), its usage afforded a "rebellious" Third World (Acharya, 2018: 202; Connelly, 2003) with a critical tool (Betts, 2016: 65-66) of world re-ordering and status enhancement, which it commonly used against stalwart colonial European empires, and eventually also against the US.

To clarify, I am not arguing that in the postwar period all states sincerely cherished and promoted "humanity" across its many varied meanings and implications. This is untrue for all major state groupings, and though all may have endorsed preferred "humanity-related" causes and standards internationally, all simultaneously ignored or downplayed others, or betrayed their own rhetoric in practice. Rather, my precise claims are two. First, international social competition between West, East, and the Third World characterized much multilateral diplomacy in the postwar world (Burke, 2010; Dinkel, 2019; Gaiduk, 2013; Heiss, 2015), and in that positional struggle for status, all groupings mobilized (and instrumentalized) the value and promotion of 
"humanity" in diversely convenient ways, while overall working diplomatically to avoid being seen as anti-humanitarian or inhumane (Best, 1994: 410). ${ }^{4}$

Amid postwar social competition via multilateral diplomacy, reforming international law became an explicit preoccupation of Third World statesmen, diplomats, and scholars pursuing status recognition (as legitimate participants) and status enhancement (as protagonists and influential rule-makers), as well as the rectification of concrete biases embedded in legal rules (Abi-Saab, 1962, 1973; Dinkel, 2019: 142) including in IHL (Abi-Saab, 1979). In 1962, Egyptian legal scholar (and later diplomat) Georges Abi-Saab wrote that "the basic attitude of the newly independent states is a revolutionary one. They want to change the status quo, and are striving to restructure... international society" (Abi-Saab, 1962: 104). Such deep restructuring explicitly entailed addressing "several orders of hierarchy" pervading the international legal order (AbiSaab, 1973: 65) Other prominent Third World leaders and scholars echoed this sentiment, including Mohammed Bedjaoui (Özsu, 2015). Borrowing Getachew's term, for Third World states at this time remaking international law was not just a narrow manipulation of multilateralism to secure instrumental gains, but a broader act of "worldmaking" (Getachew, 2019), reshaping international society by reforming international law away from imperialism and colonialism.

Crucially, in postwar multilateralism the Third World held a strong normative, political, and numerical upper-hand. Normatively, the successful delegitimation of colonialism and imperialism gave Third World states special moral power in diplomatic forums, helping them to more easily promote their stances on key issues such as development, human rights, and selfdetermination (Emerson, 1965; Jacobson, 1962; Kay, 1970). Politically, given the Cold War

\footnotetext{
${ }^{4}$ Sovereign non-interference was also a highly-cherished postwar norm for the Socialist and Third worlds (Acharya, 2018; Finnemore, 2003) yet it did not inhere in every normative aspiration and it was not invoked by Third World and Socialist states in the context of international conflict (unlike in internal conflict).
} 
competition between East and West to expand their respective spheres of influence, Third World states were actively courted as potential allies, giving the former additional political leverage, and the latter a disincentive to openly obstruct Third World causes (Dinkel, 2019: 214-226; McMahon, 2013). Finally and perhaps most critically, the Third World's growing numerical advantage sharply increased their ability to prevail in multilateralism: By 1967, decolonized states represented $45.5 \%$ of the UN membership (Kay, 1970), affording them crucial agenda-setting and decision-making advantages.

Together, these three advantages constructed a platform facilitating Third World influence in multilateral processes at the time. At the same time, not all forums were equally conducive to the deployment of Third World influence through social pressure. We know that diverse venues features afford different prerogatives and foster different effects (Coleman, 2011: 170-172; Deitelhoff, 2009: 44). Building on this insight, I argue that the probability of success for Third World social pressure was conditional on particular forum features: universal participation following sovereign equality (one-state one-vote), decision-making backed by voting, and some perceived publicity (Mantilla, 2018: 329-330).

The UN General Assembly (UNGA) became a preferred such forum for the Third World, yet IHL codification conferences shared its features. Treaty IHL is made and revised in Swiss-run and ICRC-steered negotiations open to all state parties to the Geneva Conventions which allow for majoritarian or super-majoritarian voting. Regarding publicity, as argued below and as demonstrated in the case study, the primary source of pressure for participating states emerged from intergroup dynamics within the multilateral forum. However, IHL negotiations have historically elicited scattered attention from the local Swiss press, the domestic press of participating states, or international press agencies, such that diplomats' perception that their 
actions could "get out" and reach a loosely-conceived "global public" (Dinkel, 2019: 185) -- thus provoking opprobrium -- also played a constraining role.

While I theorize these institutional features as conducive conditions, ultimately social pressure is activated through collective political agency, specifically the formation of an overwhelming, near-universal coalition capable of casting a generalized threat of opprobrium upon skeptics that might find themselves in an utter global minority (Mantilla, 2018: 330). The importance of a perceived threat of universal or global opprobrium distinguishes my argument from work that insists exclusively on the influence of peer (or in-group) pressure (Johnston, 2008: $80)$.

To activate (or counteract) social pressure, particular diplomatic practices are critical (Pouliot, 2016). Without fully developing a practice-based analysis in this article, I highlight one key diplomatic practice through which the Third World and Socialist coalition deployed social pressure, and another which allowed skeptics to engage in leadership capture. First, the tabling of resolutions sponsored by actors representing all major geographical groupings became essential for triggering consideration of IHL revisions in 1968. Second, the use of Working Groups conducting negotiations off-the-record enabled US-USSR's leadership capture, thereby decisively shaping outcomes.

\section{Methodology}

I draw on primary data collected in three national archives (UK, US, and France) and the ICRC. I gathered most documents available at these archives pertaining to the process of IHL revisions in the 1970s. These include government and ICRC preparatory documents prior to the start of official negotiations as well as those produced during and immediately after negotiations: 
inter-agency memos, instructions, telegrams, and reports. The period covers roughly the years 1965-1977. I organized these documents chronologically to allow for careful process-tracing to identify, theorize, and adjudicate between operative mechanisms (Bennett and Checkel, 2014). The fullest documentation available comes from the British National Archives; wherever there are gaps, especially in the American files, I draw carefully on British accounts of American views.

\section{Crafting Wartime Civilian Protection Rules}

Since the 1920s the ICRC had several times tried and failed to compel states to codify the protection of civilians from warfare. Most prominently at the 1949 Diplomatic Conference that revised the Geneva Conventions, and later again in the 1950s, an Anglo-American-led Western group still able to wield numerical majorities (Mantilla, 2017) mobilized behind-the-scenes to ensure that any such ICRC proposals sank. Such deliberate backstage sabotaging early into the postwar era suggests already that the US and the UK perceived opprobrium-inducing pressure in relation to this issue. A key missing factor in the 1950s, however, was a large mobilizing state group that could promote civilian protection without relying on Western consent. Decolonization "produced" such a group.

\section{Creating Social Pressure}

Third World efforts to re-order international organization and law began in earnest in 1955 with the Bandung Conference (Eslava et al., 2017). However, sustained Third World interest in IHL started to brew decisively in the early 1960s as the Algerian war ended (Bedjaoui, 1961). As noted, Third World states came to view remaking IHL as a means to enact international recognition of their status, goals, and ideas as equal, to perform active leadership in steering IHL away from 
colonialism -- thereby seizing visible (status-enhancing) protagonism in reshaping international society -- and to address concrete rule changes, particularly dealing with the legitimation of national liberation war, the protection of so-called "freedom fighters", and the limitation or prohibition of acts and weapons of war used by Western states (affecting both freedom fighters and civilians).

The IHL revisions project emerged in 1968 at the UN International Conference on Human Rights in Tehran (UN, 1968). Acting as critical diplomatic broker at this initial stage was Irish diplomat, legal scholar and advocate Séan MacBride, then Secretary-General of the International Commission of Jurists (ICJ), who became preoccupied with IHL's inadequacy for restraining abuse against civilians. Before, during and after the Tehran Conference, MacBride liaised with delegates from Third World countries, encouraging coordinated action to promote IHL revisions.

Through MacBride's efforts, at the Tehran conference India tabled a crucial resolution (XXIII) on this issue, with co-sponsorship from Afghanistan, Denmark, Finland, Indonesia, Iraq, Jamaica, Jordan, Morocco, Norway, Philippines, Sweden, Uganda, United Arab Republic (Egypt), Yugoslavia and Zambia. Sixty-seven states voted for the resolution, none against, and only South Vietnam and Switzerland abstained. ${ }^{5}$

Adoption of the 1968 Tehran resolution achieved two key outcomes. First, for the first time in history it wrestled debates on IHL development away from the "apolitical" ICRC/Red Cross movement, shifting them to the UN where politics ran high and Western states were the minority. Second, the resolution signaled that the IHL revisions project relied on broad support. According to MacBride, "it was essential in the prevailing atmosphere to secure an 'uncommitted' sponsorship and one which was representative of the various geographical groupings... This

\footnotetext{
${ }^{5}$ South Vietnam abstained presumably in response to a different ICJ-sponsored resolution against atrocities committed in that country (Suter, 1984: 33). Switzerland abstained because the resolution treaded into ICRC territory.
} 
sponsorship... was ideal and probably the only political and geographical combination that could have secured a quasi-unanimous support... The major powers... were far from happy about the resolution, but they could not afford to oppose" (cited in Suter, 1984:29, italics mine). This became a common diplomatic practice moving IHL revisions forward from 1968 through 1970.

After Tehran, MacBride continued liaising with key states from the original sponsoring coalition, with the ICRC, and with high UN officials, including Secretary-General U Thant, to see that a follow-up resolution came before the UNGA in December 1968. Again tabled by the Indian delegate, this UNGA Resolution (2444) on "Respect for Human Rights in Armed Conflict" was sponsored by "a cross-section of the membership of the United Nations [representing] the widespread concern felt throughout the world for the preservation of human rights in armed conflicts" (cited in Suter, 1984: 53). Crucially, this resolution again drew universal, unanimous support (95-0-0), bolstering the legitimacy of the IHL revisions project, as did another resolution presented a year later in Istanbul at an International Red Cross Conference. There, an ad hoc mixed coalition of states comprised of Algeria, Bulgaria, Upper Volta, Czechoslovakia, East Germany, Poland, Netherlands, Sweden, Switzerland, Canada, and Yugoslavia steered the drafting process (USNACP-2).

These cumulative resolutions, sponsored by the Third World, Socialist, and Scandinavian states signaled global support, hence pressure, for IHL revisions. British and American archival evidence demonstrates this. By 1970, the British recognized with resignation that the movement to revise IHL was now "so strong" that they could no longer avoid it (UKTNA-1). The IHL expert advising the British government explicitly decried the "formidable" force the revisions project had gathered (UKTNA-2) underscoring the unanimous support behind the 1968 UNGA resolution (as "a major landmark") owing to the state supporters of "freedom fighters" and "wars of liberation" 
(i.e. the Third and Socialist worlds) and overall remarking that these developments should be "viewed in the context of contemporary international tensions and the newer manifestation of irregular methods of fighting" (UKTNA-2, my italics).

US officials shared this analysis. American delegate Richard Baxter admitted that IHL revisions were driven by "[i]nterest on the part of the [Third World-led] human rights constituency within the United Nations, pressure exerted by the United Nations in the form of a threat to move into what had heretofore been the preserve of the [ICRC], and the accumulated concerns of the ICRC" (Baxter, 1977: 167). US Defense Department officials explicitly lamented that debate about IHL within the UN had shifted from discussing improvements in implementation to considering the regulation of "weapons, tactics, and targets", which they staunchly opposed (USNACP-3). Beyond Third World pressure, connection to Cold War social competition was evident in American analyses, as they noted that this new emphasis was also due to "Soviet maneuvering" which made the contemporary revisions proposals "an insidious threat which should not be ignored and could be embarrassing if a prompt United States response is not made. Any initiatives that would result in abstention, negative vote, or deferment in the General Assembly... would be equally damaging" (USNACP-3). Further, US State Department officials analyzing the movement toward IHL revisions had duly noted the Soviets' previous hypocritical politicization of human rights law within the UN (USNACP-4).

Interestingly, and consistent with my argument, despite their discomfort with the process and substance of the move toward IHL revisions, neither the US or the UK voted against the resolutions reviewed earlier. Both intuited political motives by the Third and Socialist worlds, but opted against expressing public discomfort or boycotting/derailing the process through threats of exit or side-payments. Instead they remained engaged, simultaneously reasoning that there was 
little chance of reversal and that they should try to manage the process from within. Importantly, despite not showing public opposition, both the US and the UK expressed interest in shifting the forum of debate from the UNGA (where per UK delegates "the Afro-Asians" had a "built-in majority") to the ICRC, which would presumably offer "a calm atmosphere devoid of acrimonious political discussion" (UKTNA-3).

\section{Vietnam Effects?}

Beyond diplomatic social pressure, one might expect the American Vietnam experience to have drawn the country into IHL revisions. I agree that Vietnam somewhat helped to relax previously-stringent American attitudes, yet my primary research shows that it was not civilian protection but the protection of American prisoners of war (POW) that prompted the change. During the war the North Vietnamese denied IHL protection to captured Americans whom they deemed "war aggressors" (Levie, 1969) such that by 1968 the US Defense Department identified this as an important concern meriting legal revision (Mantilla, n.d.). POW protection and improving IHL's implementation mechanisms thus became the key initial American concerns.

There is no denying that tremendous domestic uproar emerged in the US as allegations of American atrocity against civilians became public (especially after the My Lai massacre), expressed through mass mobilization and congressional oversight, among others (United States Congress, 1974). Yet I find no primary evidence connecting this pressure directly to the attitude of American officials and diplomats coordinating IHL revisions. In fact, as late as 1972 Major General George S. Prugh Jr. (then Judge Advocate General of the US) opined that the distinction between civilians and combatants during armed conflict was "virtually impossible" and that "civilians in any case bore much of the responsibility for a war which they supported by their 
efforts" (UKTNA-4). Hence, while US high-level "learning from atrocity" regarding civilian protection did eventually occur (Crawford, 2014; Dill, 2014), this seems to have happened over time and not immediately after My Lai as IHL negotiations were ongoing.

\section{The Travaux Préparatoires (1971-1973)}

ICRC-sponsored treaty pre-negotiations occurred in 1971 and 1972. These Conferences of Government Experts helped the ICRC measure the political temperature among states around specific revision areas. Although no votes, decisions, or verbatim records were taken at these events, archival research offers evidence of continuing Western opprobrium-avoidance and Third World and Socialist pressure across issues, including civilian protection. "We should not adopt a too negative attitude and should avoid any impression of being obstructionists," counseled UK instructions to its delegation in 1971, "at the same time making sure that any recommendations or proposals emanating from the Conference would not, if eventually accepted, be embarrassing to [Her Majesty's Government] (UKTNA-5). Third World and Socialist states (acting separately or together) nevertheless put forth several draft rule proposals that openly clashed with Western views (ICRC, 1972: 70-81), clarifying that for most such states either strict rules or prohibitions were necessary: the civilian population and civilian objects should never be made the object of attacks, and attacks whose targets could not be definitely established as being of a military character should be cancelled. Smaller European states such as Sweden, Switzerland, the Netherlands, or Norway (and Latin Americans such as Mexico) supported these stances, frustrating Anglo-American efforts to generate consensus within the West, and continuing to add to the impression that a large and mixed global majority, comprising both competing states and Western peers, opposed their views. For their part, the Anglo-American delegations found both prohibitionist or overtly detailed 
rules undesirable. To them, only "clear and simple" rules that were flexible enough to be militarily practicable were acceptable (UKTNA-6; UKTNA-7). The UNGA also continued monitoring the travaux, considering reports of the ICRC meetings and adopting resolutions to encourage further work. In that context, Anglo-American concerns with opprobrium through express opposition were also evident. They were careful to avoid leading efforts to sideline particular issues, especially weapons prohibitions or the prohibition of reprisals against civilians (UKTNA-8). British UN diplomats made soundings to ensure they would be voting in "respectable" company regarding various issues; voting in isolation or in "bad company" was avoided (UKTNA-9).

By 1972, two aspects of the Anglo-American position on civilian protection had shifted due to social pressure. First, the US and UK no longer disputed that some new rules could emerge. Second, they framed their rule design preferences ( "best efforts", flexible rules) as a "realistic" alternative to the majority's strict or prohibitionist views.

Bridging these two positions then became one of the ICRC's toughest tasks. Although it adamantly supported wide civilian protections, the ICRC knew that the new rules should accommodate military operations. It settled on a "balancing" approach, combining absolute principles of protection with specific, slightly-qualified operational rules. An ICRC draft article declared for instance that: "The civilian population as such, as well as individual civilians, shall never be made the object of attack... Attacks which, by their very nature, are launched against civilians and military objectives indiscriminately, shall be prohibited... Nevertheless, civilians who are within a military of objective run the risks consequent upon any attack launched against this objective" (ICRC, 1972: 7)

Anglo-American proposals both struck a different balance, however. While considering the draft ICRC article above, British delegates replaced the word "never" with "not," and deleted 
the expression "by their very nature" in exchange for the qualifier "intentionally" (UKTNA-10). In other places, where ICRC language denoted absolute prohibition, British analysts demanded either adjectives suggesting the rule's optional character, or inserted clear exceptions. One key example dealt with the proposed obligation for combatants to take precautions when attacking. While the ICRC text declared that combatants "shall ensure that the objectives to be attacked are not civilians, nor objects of a civilian character" and that when this could not be established combatants "shall refrain from launching the attack" (ICRC, 1972: 8), the British position was that this provision was undesirable as binding because despite a commander's effort "the data need to take objective decisions (for example statistics on the size and proportion of the civilian population) are not available and will never be available" (UKTNA-11).

As before, during the preparatory conferences the greatest challenge to the AngloAmerican line came from the majority endorsing strict or prohibitionist rules. British accounts recognized the pressure placed upon the West for its isolated position. "The basic aim of giving greater protection to the civilian population... was espoused by all; it is clearly the sort of proposition that it is [sic] difficult to produce respectable reasons for opposing" (UKTNA-12). They recognized the potential social cost in a context where the Soviet Union and the Eastern Bloc posed as the "champions of a scale of protection for the civilian population... which they would not dream of attempting to apply in any given conflict", reportedly losing "few opportunities for attacking the Americans for "callous militarism"” (UKTNA-13). That social competition was driving this attitude was clear to British officials; as they noted, the protection of civilians "is a field where the Eastern bloc seek to make political capital out of Western reluctance to concede greater protection for civilians" (UKTNA-14). Anglo-American delegates perceived the Communist position as hypocritical, noting that "certain of the Delegates, eg. those of Hungary 
and of Yugoslavia," had told them in private that "their aim was, quite simply, to make the rules so difficult that war would be virtually impossible" (UKTNA-13). ${ }^{6}$ Perceived Communist hypocrisy notwithstanding, the risk of generalized social pressure continued to weighed heavily in their analysis: "it looks as though it will be well worth reconsidering our attitude on these particular Articles among others to avoid a damaging isolation on positions which many people, including some of our friends, find over-rigid and inhumane" (UKTNA-15). This was, for instance, the case of an over-broad definition of military objects, which left it up to the "opinion of the operational commander in light of the information available to him at the time" to decide if an attack was militarily advantageous. According to British reports, "Virtually all Delegations which spoke on it considered that it allowed the military far too much latitude. Even our colleagues from the Western Group, apart from the USA, held this view" (UKTNA-16). US delegates were more optimistic, noting that although their overall approach "caused a certain amount of hostility against [us, we believe] this tactic will help produce a consensus on reasonable and desirable provisions" (USNACP-5).

This optimism was continuously frustrated, however. Despite Anglo-American efforts to steer the working texts closer to their preferences, the emerging ICRC civilian protection drafts tended to restrict military latitude, leading British and American delegates to complain that the ICRC was taking the views of other state groupings but not those of the West (UKTNA-17). To this the ICRC politely replied that it was also under pressure to accommodate the demands of the Third World, with which it needed to maintain good relations (UKTNA-18).

This evidence further confirms that, jointly, Third World and Socialist pressure shaped the political process behind the civilian protections rules, not only through preparatory conference

\footnotetext{
${ }^{6}$ According to French delegates at this conference, the Soviets were "radically hostile" to the idea of proportionality (FRA-1).
} 
debates but also backstage, by providing the ICRC with arguments to hold a stronger humanitarian line vis-à-vis the military-inclined Anglo-American position.

Expecting to find the forthcoming draft treaties partially objectionable, by mid-1973 Anglo-American concerns turned to the negotiation procedure. Knowing that consequential changes to the law could be forced through the vote, Anglo-American delegates thought it essential that a supermajority rule (two-thirds of those present and voting) should be used in Plenary, allowing a chance to organize a "blocking" coalition. They viewed the alternative (simple majority) as placing them at a hopeless disadvantage vis-à-vis the Third World, from which they were now beginning to expect extreme pressure in Conference. "We shall need about 40 likeminded [states]" to create a "blocking third" noted a British official (UKTNA-19).

Luckily for the anxious Anglo-Americans, the Swiss hosts already planned to propose this decision-making formula, shifting British and American attention back to ensuring that the substance of the APs was not pre-judged in the Conference lead-up. This could have reasonably happened through resolutions adopted in two meetings occurring just prior to negotiations: an International Red Cross Conference in Tehran, and at the UNGA, both in late 1973. However, the major controversies at those meetings surrounded topics other than civilian protection (particularly weapons and the participation of national liberation movements). Thus, while not directly relevant to my discussion here, those debates reconfirmed Anglo-American expectations that the Third World would come to the Diplomatic Conference ready to impose its views counting on Socialist bloc support.

The First Round (1974) 
The revised ICRC draft texts submitted to the Diplomatic Conference continued to displease the Anglo-American delegations. Both made plans to press for key changes, finding some articles "unacceptable" in whole or in part (UKTNA-20; UKTNA-21). This included, for instance, language limiting the conditions under which civilians could be targeted, or broad working definitions of key concepts such as (immune) civilian objects, objects essential to the survival of the civilian population, dangerous forces and installations threatening to harm civilians, as well as the ICRC-proposed precautions when attacking. In all these cases, the British and American delegates wished to drop adjectives restricting key terms such as military advantage and indiscriminate attacks, and preferred references to "feasible" (instead of "necessary") steps to uphold the rule of distinction, or "feasible" efforts "to minimize" loss of civilian life, instead of not causing any altogether (UKTNA-20; UKTNA-21).

The First Session of the Diplomatic Conference opened in February 1974 to tumultuous debates over procedure, participation, and substance. Agreement proved so difficult that four sessions (1974-1977) became necessary to conclude negotiations. Demonstrating the pressure experienced by Anglo-American delegations at the outset, the US lamented being "at the mercy of approximately a 2 to 1 majority of Africans, [Eastern European countries], some Asians, Sweden, Norway and friends [which] show no inclination to behave reasonably or apply any rational standards to the carrying on of the debate... This augers (sic) ill for... the development of reasonable rules of law" (USNACP-6).

Given the precarious voting situation, the American delegation placed crucial importance in attaining official posts within the Conference that might otherwise enable them to shape outcomes. American delegates successfully managed to be assigned the Rapporteurship of 
Committee III, ${ }^{7}$ debating the critical civilian and POW protections. Considered by the US as a "principal accomplishment" (USNACP-7), this Rapporteurship eventually proved critical, as it allowed two specific American delegates, Richard Baxter and George Aldrich, who came to negotiations bearing robust legal and diplomatic credentials (Baxter was Professor of International Law at Harvard, Aldrich was a long-serving State Department Legal Advisor) to position themselves as brokers. As seen below, such legal-diplomatic competence became crucial once agreement failed on thorny aspects of the rules during open negotiation.

As predicted, initial open debates (in 1974) on civilian protection within Committee III revealed the balance of opinion to strongly favor rule strictness or prohibitionism against Western "flexibilism". China promoted prohibitionism in the most politically charged terms: "In view of the cruel oppression and heavy casualties suffered by the civilian population in the aggressive wars launched by the imperialists, colonialists, racists and Zionists, Protocol I should provide for the maximum protection of civilians" (Levie, 1980: 64). Syrian delegates asserted that they "could not accept the theory of some kind of 'proportionality' between military advantages and loses and destruction of the civilian population and civilian objects, or that the attacking force should pronounce on the matter" (Levie, 1980: 127). Hungary decried proportionality as well, "which called for a comparison between things that were not comparable, and thus precluded objective judgement" (Levie, 1980: 128). Ghana concurred that the principle of proportionality, and language balancing civilian immunity with expected military advantage, should be deleted as being anti-humanitarian and open to abuse due to their ambiguity (Levie, 1980: 132).

\footnotetext{
${ }^{7}$ By the Swiss hosts probably in close consultation with the ICRC.
} 
Of all states speaking in public Committee debate in 1974, the large majority (again largely a mix of Third World and Socialist states) did so in favor of the strict or prohibitionist stance. ${ }^{8}$ Western powers were accordingly flustered. The 1974 British post-Conference report lamented other states' willingness “to espouse any idea, however legally imprecise and practically unworkable, so long as it looked 'humanitarian"”, essentially "pinning paper flowers on the text" (UKTNA-22). Importantly, they noted that "it became clear that... no text with United Kingdom on it would ever command the general acceptance enjoyed by one sponsored by one or more AfroAsian states" (UKTNA-22). American Head of Delegation George Aldrich similarly decried the:

"...widespread ignorance among the participants in the Conference of both war and humanitarianism as an 'art of the possible.' Delegations would not infrequently call for prohibitions of activity... on the grounds that it is 'inhumane.' They were insensitive to compromises that the law must make... many of the less developed countries seemed unable to cope with the distinction between 'unavoidable suffering' and 'unnecessary suffering' in warfare" (USNACP-8, italics mine). This is clear evidence of social pressure at work, and reveals a shared Anglo-American anxiety over the potentially-forced adoption of militarily-"unworkable" rules (UKTNA-22).

The draft civilian protection articles adopted in 1974 (draft Arts. 48, 49 and 50) all represented compromises, sometimes moderating the militarily-inclined view of Western states, particularly in enshrining a general presumption of civilian status in case of doubt. Importantly, these articles were negotiated mainly within a Working Group (WG) created by the Committee III in one of its earliest meetings. The practice of using WGs to foster agreement is of course common

\footnotetext{
8 Supporting prohibitionism in 1974 were: Syria, Hungary, Ghana, Czechoslovakia, West Germany, Poland, Mongolia, Iraq, Egypt, China, Romania, Norway, North Korea, Uganda, Mauritania, India, Indonesia, Albania, and Vietnam. Opposing it were: Finland, Canada, Uruguay, Australia, UK, France, US, USSR.
} 
in multilateral negotiations, and there is nothing inherently unusual about their usage by Committee III. Yet as noted, given the voting advantages of the Third World and Socialist coalition amid IHL revisions, and with agreement within open debate proving elusive, reliance on alternative methods to produce agreeable texts became simply crucial for the Western minority. Indeed, from 1974 onwards the WG was where most of the work (or where the "real" work) was done (UKTNA-22; UKTNA-23).

Participation in the WG was open to all members of the Committee but in practice not all attended. Such varying attendance, and the presence or absence of particular delegations, mattered greatly for debates (more on this below). Also crucially, the WG did not keep verbatim transcripts, but instead tasked the Rapporteur with summarizing WG discussions, emerging agreements, and textual compromises. Through this Rapporteurship, American delegates compensated for their voting disadvantage and became hugely influential, and later, as US-Soviet backstage cooperation congealed shortly after the 1974 session closed, American WG Rapporteurship became critical to legal outcomes on civilian protection.

To be fair, the WG did seem to engage in prolonged debate, reflected in a high number of meetings and in the Rapporteur's own (semi-detailed) narrative. Therefore my claim is not that the WG was a simple cover for sheer Anglo-American predominance. Moreover, the WG did not have authority to decide on the substance of the draft rules; instead, it relayed its debates and proposals through Rapporteur-penned reports to Committee, which then evaluated the compromises and, when necessary, voted on parts of them. ${ }^{9}$ Thus, neither the WG nor the Rapporteur could simply impose decisions on the Committee.

\footnotetext{
9 Though roll-call was not used and thus states' positions were not revealed.
} 
However, in deciding what counted as an emerging consensus, interpreting the thrust of the WG debates, and actually drafting textual alternatives and presenting them as working compromises, the WG's Rapporteur exerted critical framing influence, which did not go unnoticed. British diplomats celebrated that the WG reports "were particularly valuable because written from a US viewpoint... which frequently coincided with that of the UK" (UKTNA-23), also noting Swedish and Norwegian protestations that the WG reports were in parts "simply the Rapporteur's own view" (UKTNA-23).

Two additional comments regarding the use of the WG in 1974 seem important. First, the WG did not generate broad backlash, and became the Committee's standard operating procedure. Lacking access to Third World or Socialist archives, it becomes difficult to ascertain how those states privately viewed American Rapporteurship, or WG proceedings. To British delegates, however, American delegate's Richard Baxter WG Rapporteurship had proved a very helpful force, "because he is both widely respected and very skillful at steering draft sessions in a way favourable to Western view-points without this being at all apparent" (UKTNA-22). This diplomatic "competence" or "mastery" (Pouliot, 2016: 55-59) was shared with the American Head Delegate, George Aldrich, who assumed the Rapporteurship in 1975.

Second, in 1974 a camaraderie seems to have developed between the Anglo-American delegates and the Chairman of Committee III, the Egyptian delegate Professor Sultan, which reportedly became crucial for subsequent compromise-making. This emerged in Aldrich's confidential 1974 report to the US government, which noted that while the Egyptians had been core supporters of unpalatable proposals dealing with national liberation, their delegation also "showed itself to be conciliatory and conscious... and on more than one occasion was helpful in getting other states in the same camp off their more extreme positions" (USNACP-9, italics mine). 
Thus, in addition to helping Committee III run more smoothly, the reportedly "excellent relationship" (USNACP-9) between Americans (as Rapporteurs) and Egyptians (as Chairman) contributed to promoting Egyptian brokerage within the Third World.

Among Third World delegations, the Egyptians were ideally suited to act as key participants and brokers: they possessed outstanding legal skills, as three of its principal members were professors of international law (Sultan, Al-Ghunaimi, and Abi-Saab); they held moderate views; and, as just noted, they had great relations with the leading Western delegation. ${ }^{10}$ Egyptian brokerage soon proved critical for compromise, yet as explained below, their assuming of the (informal) role as Third World spokesmen (Abi-Saab, 2016: 1965) -- likely granted to them because of their outstanding legal competence - also inevitably deflated the initially overwhelming social pressure.

In 1974 the Committee III did not debate the toughest issues dealing with civilian protection: the rules on proportionality (Art. 46 and 50) and precautions before attack (Art. 50). The "prohibitionist" tone of the debate rather alarmed Anglo-American delegates, motivating them to find ways to arrest the strong majority coalition.

\section{Leadership Capture}

The initial inter-sessional (1974-1975) Anglo-American strategy was to enlist stronger support for their "realistic" position on a range of issues, including civilian protection. Yet, archival records suggest that in addition to any such efforts, a modified backstage strategy emerged from an unlikely source: the USSR. ${ }^{11}$

\footnotetext{
${ }^{10}$ Georges Abi-Saab had been a student of Richard Baxter's at Harvard Law School a decade earlier.

11 This section draws and expands upon previous work (Mantilla, 2019: 198-202).
} 
American cables confirm that as early as November 1974, Soviet delegates reached out to their American counterparts and proposed holding bilateral meetings to coordinate their views. A US cable from November 8, 1974 noted: "During informal side discussion... Blischenko (USSR) repeatedly urged Bettauer and Anderson of USDEL that it [is] essential that USG and USSR have bilateral consultations in advance of second session. [State] Department agrees that such consultations would be desirable and useful" (USNACP-10). ${ }^{12}$ The first such meeting took place on February 1, 1975, to mutual satisfaction: "consultations, which avoided Vietnam issue, showed largely similar positions. [The Soviets] were very appreciative of being invited to consultations and of cordial atmosphere. We agreed to consult further as required during conference" (USNACP-16). And in 1977, serving as definitive confirmation of this useful strategic collaboration, the American Head Delegate admitted that: "[at] the second session of the Conference in 1975, many votes were taken but with a difference. Most of the fundamental disagreements were first worked out through negotiated compromises [between the US and USSR]" (Aldrich, 1977: 11).

This alignment is a remarkable and thus-far underappreciated instance of US-Soviet cooperation in the final years of détente. Why would the USSR switch from supporting the prohibitionist stance, through which it reaped social-competitive benefits, to collaborating with its ostensive public rival, the US?

In my view, the explanation lies at least partially in the complex sociopolitical dynamics of the postwar era. As noted, East-West international social competition offered the USSR incentives for public posturing and propagandizing on a range of issues during IHL revisions, including civilian protection. Yet as negotiations advanced and the threat of adopting prohibitionist

\footnotetext{
${ }^{12}$ Further US telegrams confirm these consultations were held and continued until at least 1977 (USNACP-11;
} USNACP-12; USNACP-13; USNACP-14; USNACP-15; USNACP-16; USNACP-17). 
civilian protection rules increased, USSR delegates appear to have opted instead for containing them, likely realizing they too would become subject to prohibitionism. Crucially, and consistent with my argument regarding the disciplining power of humanity-promotion at the time, USSR delegates decided to act privately, both to avoid being seen as inhumane and to be seen openly collaborating in public with the US, a move that might potentially alienate the Third World and fellow Socialist states.

Lacking access to Soviet archives, my claims regarding USSR attitudes remain tentative, yet American and British cables suggest Soviet sensitivity to social pressure at the Conference (USNACP-11) prompting them to seek opprobrium-avoiding "alternatives" to simple public obstruction. One telegram records Soviet awareness that the second session of the Diplomatic Conference "would be under considerable pressure to produce something" and that, in the eyes of Soviet representatives "this pressure was directed at both the Soviets and the Americans by third countries" (USNACP-11). More explicitly, on the Soviet attitude toward weapons regulation (formally separate from civilian protections but intimately tied to it), a British official privately wrote in 1975: "It seems to me that [our] basic approaches to this subject are indeed similar. We are both concerned to give some sort of positive response to international humanitarian pressure; on the other hand, we wish to resist unrealistic prohibitions" (UKTNA-24, italics mine). The British recognized the opportunity to ally with the USSR in order to improve their political position, for which the coordination of their diverse tactics would be necessary: "Our objective should be both to reassure them [that they agreed on substance]... and at the same time to try to persuade them to make a more credible effort to share their thinking with the international weapons community; it puts the West in an invidious position if we are left to be the only ones to deploy research-based arguments against the Swedes etc. Yet if we were to give up on this for lack of 
matching Russian effort, both the Russians and ourselves might well expect to suffer under an increased weight of international opinion" (UKTNA-24, italics mine).

US-USSR rapprochement amid IHL revisions was certainly facilitated by the broader context of détente (Bowker and Williams, 1988). Yet importantly, even during détente public Cold War posturing or propagandizing between East and West did not abate. The Soviets remained interested in pillorying the West whenever possible (especially while supporting the Third World) even as they cooperated with the US to secure mutually beneficial outcomes. As Snyder notes, in this period there was "a larger ongoing Soviet-American dialogue about how to reach agreements without appearing to circumvent the multilateral proceedings" (Snyder, 2013: 25). Simultaneously, and at least until the late 1970s, leading states from West and East tried to minimize crossing the Third World by avoiding public obstruction of many of the latter's cherished demands. Overall, dynamics of frontstage competition and backstage collaboration shaped the making of international agreements at this time, including the revision of IHL.

The records of the private US-USSR meetings are unavailable, yet the general strategy appears clear (Mantilla, 2019: 199). Both coordinated "to ensure that any provisions adopted were acceptable to both of them and their allies" (Aldrich, 1977; USNACP-16), hoping to minimize criticism in Committee III and clear the path to adoption of compromise texts they liked. American allies presumably included the rest of the Western Group, Latin American states, and moderate delegations within the Third World, particularly Egypt, which could help placate insistence on “extremist” proposals in 1975.

Archival evidence supports this analysis. Per the British delegation's 1975 report, Third World attendance in Committee III that year overall "was patchy and their contributions few". This had various sources. Most contingently, per the UK report, the absence of certain delegations, 
(e.g. "the strident Mr Allaf of Syria who did so much harm in 1974") mattered. Second, a key legal-political change attained elsewhere in API during the 1974 session -- the legitimation of national liberation war as an international conflict -- reportedly reduced Third World enthusiasm in debating rules requiring more technical-legal knowledge, including civilian protection. Relatedly and most importantly, Egypt's informal Third World spokesmanship proved essential; as the British reported, in the 1975 "the Arabs, and the Third World generally, were led instead by the unfailingly courteous and sensible Professor Alghunaimi of Egypt" (UKTNA-23). Additional primary evidence further confirms the critical Egyptian influence via the Chairmanship and amid Committee III (and WG) debates, moderating the once-intensely politicized Third World stance. Regarding WG debates about draft Article 49, regarding the prohibition of attacks on works and installations containing dangerous forces, a UK telegram observed that "following the behind the scenes activities by the USA and Egypt, [it] seems to be coming out in a reasonably acceptable manner" (UKTNA-25).

The Soviets too seem to have effectively liaised and moderated most of Eastern bloc state attitudes, ultimately narrowing such opposition to one or two Socialist states, notably Romania. Thus, per British remarks, in 1975 Eastern European states had shown a "generally co-operative" attitude (UKTNA-23).

The second aspect of the US-USSR strategy relied on American WG Rapporteurship. Since the WG did not produce verbatim records, only the American Rapporteur's own account informed Committee debate (FPD, 1978b: 266-288). Though not naming specific states, the WG reports were reasonably detailed (Mantilla, 2019: 200). They described the difficulty of crafting compromise texts, admitting to awkward phrasing (Art. 48 on the protection of objects indispensable to the civilian population) or to ambiguous qualifications and aspirational language 
("feasible precautions" in Art. 50 about protection from attacks, or "to the maximum extent feasible," in Art. 51). Yet in most cases they describe agreements reached within the WG on variously-imprecise texts, "unsurprisingly in a manner generally consistent with the US-USSR 'best efforts' approach" (Mantilla, 2019: 200). British confidential reports partially credited outcomes reached in 1975 to the "valuable steering" by Aldrich and Baxter within the WG (UKTNA-23).

In closing, when the texts were being considered for approval in Committee and Plenary, the US and USSR Head Delegates worked together: American delegates introduced the draft texts, the Soviets expressed agreement. And if amendments arose, both delegations made statements urging others not to disturb the hard-won compromises (FPD, 1978a: 299-308). Ultimately, it was thanks to US-Soviet shepherding that compromise civilian protection rules emerged from long and fractured negotiations (Mantilla, 2019: 200). ${ }^{13}$

\section{Concluding Remarks}

To what extent did social pressure affect the codification of civilian protection? Undoubtedly, the move toward IHL revisions inaugurated in 1968 pushed the two key gatekeepers of the law to consider revisions they had long rejected. As the leading American negotiator George Aldrich admitted in 1977, "a codification conference forces national decisions on limits on the use of force that would otherwise be deferred. A government does not make such difficult decisions unless it is forced to do so" (1977: 15, my emphasis). With regard to process, moreover, repeated evidence presented here points to the pressuring influence of a preponderant Third World and Socialist majority coalition operating in the multilateral setting, leading Anglo-American delegates to drop

\footnotetext{
${ }^{13}$ As noted earlier, US-USSR cooperation continued until at least 1977 (USNACP-17).
} 
their initial anti-regulation stance, engage in negotiations, and maintain a compromising attitude under the threat of social opprobrium. And given the intractable voting asymmetry in Conference, social pressure appears to have led the superpowers states to embrace the backstage strategy I label leadership capture.

Were the finally-designed rules the simple result of US-USSR machinations? Although they clearly shaped the rules into agreeable form (to them), a comparison between the negotiated texts and the draft American and British instructions from 1974 reveals critical disparities between their more restricted initial preferences and the final compromises. Both delegations had for example been instructed to oppose the idea that civilians should be protected "unless and for such time" as they took part in hostilities. In their view, this language threatened to incentivize civilian participation in hostilities (by narrowing the timeframe in which civilians lost their immunity). The line survived negotiations, however, as did the finally-codified definition of military advantage (against which danger to civilians must be compared prior to an attack) in Articles 51 and 57, which was qualified as "concrete and direct" despite Anglo-American opposition to such adjectives. Egyptian brokerage likely also played a moderating influence on the superpowers' views on rule design, as did debates within the WG and Committee III.

On balance, then, IHL's civilian protection rules bear traces of multiple conflicting political forces and actor values and interests, and their design weaknesses reflect less an unbridled, selfserving attitude by the superpowers than their face-saving reliance on ambiguity and textual indeterminacy, deliberately used to salvage some degree of (rule-oriented) military latitude during armed conflict.

This explanation joins recent efforts to explain international order, law, and norms not as the product of simple imposition or normative diffusion and persuasion, but as a politically 
contentious, conflict-laden process of co-construction (Hakimi, 2017). My argument operates conditionally, however, hinging particularly on the status politics prevalent at the time of negotiation as well as on particular procedural features of the law-making process. Despite its conditional nature, this argument has the potential to explain other controversial cases of international law-making, including international human rights law and conventional weapons treaties. Contrast and comparison with histories and explanations of the failure of law-making featuring similar actors and factors, such as the demise of the New International Economic Order in the late 1970s or 1980s, should lead to theoretical refinement.

In the end, even while legal uncertainties around civilian protection have been and will continue to be difficult to untangle, these rules remain central to our international normative order and remain "alive" partly thanks to the disagreements they crystallized, and those they still generate (Wiener, 2018).

\section{References}

Abi-Saab G (1962) The Newly Independent States and the Rules of International Law: An Outline. Howard Law Journal 8(2): 95-121.

Abi-Saab G (1973) The Third World and the International Legal Order. Revue Egyptienne de Droit International 29: 27-66.

Abi-Saab G (1979) Wars of National Liberation in the Geneva Conventions and Protocols. In: Collected Courses of the Hague Academy of International Law. Leiden: Brill, pp. 353-448.

Abi-Saab G (2016) The Third World Intellectual in Praxis: Confrontation, Participation, or Operation behind Enemy Lines? Third World Quarterly 37(11). Routledge: 1957-1971.

Acharya A (2018) Constructing Global Order: Agency and Change in World Politics. Cambridge: Cambridge University Press.

Adler-Nissen R (2012) Diplomacy as Impression Management: Strategic Face-Work and PostColonial Embarassment. Note de Recherche, Project on Globalization and the National Security State.

Adler-Nissen R (2014) Stigma Management in International Relations: Transgressive Identities, Norms, and Order in International Society. International Organization 68(01): 143-176.

Aldrich GH (1977) Establishing Legal Norms Through Multilateral Negotiation: The Laws of War. Case Western Reserve Journal of International Law 9: 8-16.

Aldrich GH (1981) New Life for the Laws of War. American Journal of International Law 
75(4): 764-783.

Aldrich GH (1986) Progressive Development of the Laws of War: A Reply to Criticisms of the 1977 Geneva Protocol I. Virginia Journal of International Law 26(3): 693-720.

Alexander A (2015) A Short History of International Humanitarian Law. European Journal of International Law 26(1): 109-138.

Alexander A (2016) International Humanitarian Law, Postcolonialism and the 1977 Geneva Protocol I. Melbourne Journal of International Law 17(1): 15-50.

Anghie A (2007) Imperialism, sovereignty and the making of international law. Cambridge University Press.

Barnett M (2011) Empire of Humanity: A History of Humanitarianism. Ithaca: Cornell University Press.

Baxter RR (1977) Modernizing the Laws of War. Military Law Review 78: 165-183.

Bedjaoui M (1961) Law and the Algerian Revolution. Brussels: International Associations of Democratic Lawyers.

Bellamy AJ (2015) The Responsibility to Protect Turns Ten. Ethics \& International Affairs 29(2): 161-185.

Bennett A and Checkel JT (eds) (2014) Process Tracing: From Metaphor to Analytic Tool. Cambridge University Press.

Best G (1994) War and Law since 1945. New York: Oxford University Press.

Betts P (2016) Universalism and its Discontents: Humanity as a Twentieth-Century Concept. In: Klose F and Mirjam Thulin (eds) Humanity: A History of European Concepts in Practice From the Sixteenth Century to the Present. Göttingen: Vandenhoeck \& Ruprecht, pp. 5172.

Bowker M and Williams P (1988) Superpower Détente: A Reappraisal. London: SAGE.

Burke R (2010) Decolonization and the Evolution of International Human Rights. University of Pennsylvania Press.

Coleman KP (2011) Locating Norm Diplomacy: Venue Change in International Norm Negotiations. European Journal of International Relations 19(1): 163-186.

Colgan J and Miller N (2019) Rival Hierarchies and the Origins of Nuclear Technology Sharing. International Studies Quarterly 63(2): 310-321.

Connelly M (2003) A Diplomatic Revolution: Algeria's Fight for Independence and the Origins of the Post-Cold War Era. Oxford University Press.

Crawford E (2015) Identifying The Enemy: Civilian Participation in Armed Conflict. New York: Oxford University Press.

Crawford NC (2002) Argument and Change in World Politics. New York: Cambridge University Press.

Crawford NC (2013) Accountability for Killing: Moral Responsibility for Collateral Damage in America's Post-9/11 Wars. Oxford University Press.

Crawford NC (2014) Targeting Civilians and U.S. Strategic Bombing Norms: Plus Ça Change, Plus C'est La Même Chose? In: Evangelista M and Shue H (eds) The American Way of Bombing: Changing Ethical and Legal Norms, from Flying Fortresses to Drones. Ithaca: Cornell University Press.

Dayal A and Morjé Howard L (2017) Peace Operations. In: Katz-Cogan J, Hurd I, and Johnstone I (eds) Oxford Handbook of International Organizations. Oxford University Press.

Deitelhoff N (2009) The Discursive Process of Legalization: Charting Islands of Persuasion in the ICC Case. International Organization 63(1): 33-65. 
Dill J (2014) Legitimate Targets?: Social Construction, International Law and US Bombing. Cambridge University Press.

Dinkel J (2019) The Non-Aligned Movement: Genesis, Organization and Politics (1927-1992). Leiden: Brill.

Eckel J (2010) Essay-Review: Human Rights and Decolonization: New Perspective and Open Questions. Humanity 1(1): 111-135.

Emerson R (1965) Colonialism, Political Development, and the UN. International Organization 19(3): 484-503.

Erickson J (2015) Dangerous Trade: Arms Exports, Human Rights, and International Reputation. Columbia University Press.

Eslava L, Fakhri M and Nesiah V (eds) (2017) Bandung, Global History, and International Law: Critical Pasts and Pending Futures. Cambridge: Cambridge University Press.

Finnemore M (2003) The Purpose of Intervention: Changing Beliefs About the Use of Force. Ithaca: Cornell University Press.

Finnemore M and Sikkink K (1998) International Norm Dynamics and Political Change. International Organization 52(4): 887-917.

FPD (1978a) Official Records of the Diplomatic Conference on the Reaffirmation and Development of International Humanitarian Law Applicable in Armed Conflicts, Geneva (1974-1977), Vol. XIV. Bern.

FPD (1978b) Official Records of the Diplomatic Conference on the Reaffirmation and Development of International Humanitarian Law Applicable in Armed Conflicts, Geneva (1974-1977), Vol. XV. Bern.

Gaiduk I (2013) Divided Together: The United States and the Soviet Union in the United Nations, 1945-1965. Stanford University Press.

Getachew A (2019) Worldmaking after Empire: The Rise and Fall of Self-determination. Princeton University Press.

Hakimi M (2017) Constructing an International Community. American Journal of International Law 111(2): 317-356.

Heiss MA (2015) Exposing 'Red Colonialism': U.S. Propaganda at the United Nations, 19531963. Journal of Cold War Studies 17(3): 82-115.

Hoffman S-L (2010) Introduction: Genealogies of Human Rights. In: Hoffmann S-L (ed.) Human Rights in the Twentieth Century. Cambridge, UK: Cambridge University Press, pp. $1-28$.

ICRC (1969) Reaffirmation and Development of the Laws and Customs Applicable in Armed Conflicts, report submitted by the International Commission of the Red Cross, XXI International Conference of the Red Cross, Istanbul, September 1969. Geneva.

ICRC (1972) Conference of Government Experts on the Reaffirmation and Development of International IHL Applicable in Armed Conflicts, Second Session (Geneva, 3 May - 3 June 1972), Report on the Work of the Conference, Volume II (Annexes). Geneva.

Jacobson HK (1962) The United Nations and Colonialism: A Tentative Appraisal. International Organization 16(1): 37-56.

Jensen SLB (2016) The Making of International Human Rights: The 1960s, Decolonization and the Reconstruction of Global Values. New York: Cambridge University Press.

Johnston AI (2008) Social States: China in International Institutions, 1980-2000. Princeton: Princeton University Press.

Kay DA (1970) The New Nations in the United Nations, 1960-1967. Columbia University Press. 
Kelley JG (2017) Scorecard Diplomacy: The Power of Reputation to Influence States. New York: Cambridge University Press.

Kinsella HM (2011) The Image Before the Weapon: A Critical History of the Distinction between Combatant and Civilian. Ithaca: Cornell University Press.

Levie HS (1969) Maltreatment of Prisoners of War in Vietnam. In: Falk RA (ed.) The Vietnam War and International Law, Volume 2, pp. 361-397.

Levie HS (ed.) (1980) Protection of War Victims: Protocol 1 to the 1949 Geneva Conventions, Volume 2. Dobbs Ferry, N.Y.: Oceana.

Mantilla G (2017) The Origins and Evolution of the 1949 Geneva Conventions and the 1977 Additional Protocols. In: Evangelista M and Tannenwald N (eds) Do the Geneva Conventions Matter? Oxford: Oxford University Press, pp. 35-68.

Mantilla G (2018) Forum Isolation: Social Opprobrium and the Origins of the International Law of Internal Conflict. International Organization 72(2): 317-349.

Mantilla G (2019) The Protagonism of the USSR and Socialist States in the Revision of International Humanitarian Law (IHL). Journal of the History of International Law 21(2): $181-211$.

Mantilla G (n.d.) Under (Social) Pressure: The Historical Regulation of Internal Armed Conflicts through International Law. Draft book manuscript.

McMahon RJ (ed.) (2013) The Cold War in the Third World. Oxford University Press, USA.

Nair D (2019) Saving Face in Diplomacy: A Political Sociology of Face-to-ace interactions in the Association of Southeast Asian Nations. European Journal of International Relations First View.

Özsu U (2015) 'In the Interests of Mankind as a Whole': Mohammed Bedjaoui's New International Economic Order. Humanity: An International Journal of Human Rights, Humanitarianism, and Development 6(1): 129-143.

Özsu U (2016) An Anti-Imperialist Universalism? Jus Cogens and the Politics of International Law. In: Koskenniemi M, Rech W, and Jiménez Fonseca M (eds) International Law and Empire: Historical Explorations. Oxford: Oxford University Press.

Partsch KJ, Solf WA and Bothe M (1982) New rules for victims of armed conflicts : commentary on the two 1977 protocols additional to the Geneva Conventions of 1949. The Hague; Boston : Hingham, MA: Martinus Nijhoff Publishers ; distributors, Kluwer Boston.

Petrova MH (2016) Rhetorical Entrapment and Normative Enticement: How the United Kingdom Turned From Spoiler Into Champion of the Cluster Munition Ban. International Studies Quarterly 60(3): 387-399.

Pouliot V (2016) International Pecking Orders: The Politics and Practice of Multilateral Diplomacy. New York: Cambridge University Press.

Pouliot V and Thérien JP (2018) Global Governance: A Struggle over Universal Values. International Studies Review 20(1): 55-73.

Price R (1998) Reversing the Gun Sights: Transnational Civil Society Targets Land Mines. International Organization 52(3): 613-644.

Risse T (2000) 'Let's Argue!': Communicative Action in World Politics. International Organization 54(1): 1-39.

Risse T, Ropp SC and Sikkink K (1999) The Power of Human Rights: International Norms and Domestic Change. New York: Cambridge University Press.

Schimmelfennig F (2001) The Community Trap: Liberal Norms, Rhetorical Action, and the Eastern Enlargement of the European Union. International Organization 55(1): 47-80. 
Snyder SB (2013) Human Rights Activism and the End of the Cold War: A Transnational History of the Helsinki Network. Cambridge, UK: Cambridge University Press.

Suter K (1984) An International Law of Guerilla Warfare: The Global Politics of Law-Making. New York: St. Martin's Press.

Towns AE (2012) Norms and Social Hierarchies: Understanding International Policy Diffusion "From Below". International Organization 66(02): 179-209.

Towns AE and Rumelili B (2017) Taking the Pressure: Unpacking the Relation between Norms, Social Hierarchies, and Social Pressures on States. European Journal of International Relations 23(4): 756-779.

UN (1968) Final Act of the International Conference on Human Rights, Teheran, 22 April to 13 May 1968.

United States Congress (1974) Human rights in the World Community: A Call for U.S. leadership. Report of the Subcommittee on International Organizations and Movements of the Committee on Foreign Affairs, House of Representatives, 93rd Congress, 2 nd session. Washington, D.C.

Waltz SE (2001) Universalizing Human Rights: The Role of Small States in the Construction of the Universal Declaration of Human Rights. Human Rights Quarterly 23(1): 44-72.

Westad OA (2005) The Global Cold War: Third World Interventions and The Making of Our Times. Cambridge, UK: Cambridge University Press.

Wiener AE (2018) Constitution and Contestation of Norms in Global International Relations. Cambridge: Cambridge University Press.

Zarakol A (2011) After Defeat: How the East Learned to Live with the West. Cambridge University Press.

For full citation of archival references, see Supplementary File 